\title{
Études/Inuit/Studies
}

STUCKENBERGER, Nicole, 2007 Thin Ice: Inuit Traditions

Within a Changing Environment, Hanover, Hood Museum of Art and Dartmouth College, distributed by University Press of New England, 80 pages.

\section{Shari Gearheard}

Volume 31, numéro 1-2, 2007

Tchoukotka

Chukotka

URI : https://id.erudit.org/iderudit/019744ar

DOI : https://doi.org/10.7202/019744ar

Aller au sommaire du numéro

\section{Éditeur(s)}

Association Inuksiutiit Katimajiit Inc.

Centre interuniversitaire d'études et de recherches autochtones (CIÉRA)

\section{ISSN}

0701-1008 (imprimé)

1708-5268 (numérique)

Découvrir la revue

Citer ce compte rendu

Gearheard, S. (2007). Compte rendu de [STUCKENBERGER, Nicole, 2007 Thin Ice: Inuit Traditions Within a Changing Environment, Hanover, Hood Museum of Art and Dartmouth College, distributed by University Press of New England, 80 pages.] Études/Inuit/Studies, 31(1-2), 391-393.

https://doi.org/10.7202/019744ar d'utilisation que vous pouvez consulter en ligne. 
Exceptés la police de caractère un peu petite, de rares coquilles, et le regret que certaines illustrations n'aient pas été reproduites en couleurs, je ne trouve rien à reprocher à cet ouvrage dans lequel on serait en peine d'identifier des lacunes, bien qu'il présente une synthèse à des échelles géographique et temporelle proprement énormes.

\section{Référence}

HOFFECKER, John F.

2005 A Prehistory of the North: Human Settlement of the Higher Latitudes, Piscataway, Rutgers University Press.

Yvon Csonka

Department of Cultural and Social History Ilisimatusarfik, The University of Greenland Postboks 279 DK-3900 Nuuk, Greenland csonka@greennet.gl

\section{STUCKENBERGER, Nicole}

2007 Thin Ice: Inuit Traditions Within a Changing Environment, Hanover, Hood Museum of Art and Dartmouth College, distributed by University Press of New England, 80 pages.

Thin Ice is the accompanying catalogue to the Hood Museum of Art's exhibition of the same name held January 27-May 13, 2007. Nicole Stuckenberger curated the exhibition and led the production of the catalogue, also authoring the main essays that are featured in the book. A Postdoctoral Fellow at the Institute of Arctic Studies, Dartmouth College, Stuckenberger brought together the museum's Arctic collections and her own research and experience in an Inuit community to produce an exhibition and volume that "explores the lives of the Inuit people of the Arctic and their intimate relation to ice, weather, climate, and nature, the many manifestations of the Inuit concept of sila (universe, weather)" (p. 12).

When one picks up Thin Ice, there is no denying it is a beautiful book. Its large, full colour, glossy format impresses. The photographs of the collection are excellent, with several plates blown up throughout the book to fill a half or full page. With each object set against a black background, readers will appreciate, for example, seeing the details included in a miniature model of a one-man kayak (p. 11), the careful winding of twine on a 1930s Alaskan ice scratcher (p. 56), or the seam and stitch work on a seal gut parka (p. 54). Though more than a coffee table book, Thin Ice is just the kind of work that one will enjoy flipping through for the photography alone.

The textual content of Thin Ice is interesting, but not so artfully crafted as the visual aspects of the book. The book begins with a Foreword by Aqqaluk Lynge (President of the Inuit Circumpolar Council, Greenland) where he discusses the 
different perspectives and perceptions that exist between many people about climate change, including Inuit, scientists, industry, government, and media, and the need to bring diverse people together in partnership. In a separate essay that follows by Ross Virginia, Kenneth Yalowitz, and Igor Krupnik, the message of partnership is also present. This short essay describes the links of the Thin Ice exhibition to the International Polar Year, the efforts of the exhibition to explore the different perceptions and culture of scientific versus Inuit understanding of climate change, and provides a brief description of the rapid changes the Arctic faces today in environment, society, and governance. A short piece by William Fitzhugh then follows as a sort of memoir-style celebration of Dartmouth College and lastly, Kenneth Woodward provides a very detailed account of the history of Dartmouth's northern collections, and how, when and from whom they came to be acquired.

Almost half the book, these first 30 pages are fairly disjointed and seem to stand on their own. They give the feel of a (too) long introduction and acknowledgement section. As a catalogue to an exhibition, all of these acknowledgements and details may be important, but one is drawn in by the title, implying that some kind of analysis or story is to be found. We seem to arrive there with Stuckenberger's section entitled, "Thin Ice: Inuit Life and Climate Change." In the main essay of the book, Stuckenberger provides an overview of weather and climate in Inuit life. Her focus on weather and climate as integral parts of Inuit culture, cosmology, and worldview are refreshing at a time when Inuit Qaujimajatuqangit (Inuit knowledge) is often dissected into narrow observations of the environment. Stuckenberger reminds us of the many ways Inuit are "intimately tied to the climate and environment"- a statement often made, but often-times not adequately explored as Stuckenberger does in this section. The essay is well illustrated with photos from Stuckenberger's own fieldwork and she also makes reference to plates in the book's photo catalogue that depict various pieces in the exhibition. For the most part, the objects help illustrate a point or provide supporting information (e.g., catalogue no. 5, a 1976 lithograph from Cape Dorset entitled "The Seasons," helps enhance Stuckenberger's discussion of the Inuit seasonal cycle). Some connections are weak or not clear, however, such as a discussion of modern Inuit still preferring traditional ways of life (p. 37) and the link to a photo of a caribou suit (cat. no. 45).

The last part of the book is the catalogue itself, where 66 items from the exhibition appear in colour plates with annotations. In some ways the most interesting part of the book, the annotations are short and informative and help to explain the use and meaning of different tools and objects. My only criticism of the catalogue is an absence of any scale, as it was difficult to imagine how large or small some objects might be. Also in this section is a short essay by Stuckenberger and Erik Lambert entitled, "Being Hunter-Being Game-Being Social" that describes social life, camp life, and activities according to seasons. As in Stuckenberger's earlier essay, links are made to specific objects in the exhibition catalogue that enrich the story for the most part.

Taken together, Thin Ice does a good job of describing and illustrating the relationship Inuit have with their environment, how Inuit use their environment, and how Inuit life changes with seasonal weather. What is not strong or clear, however, is 
the link to the rapid climate change Inuit face today (and perhaps have faced in the past). What happens when the seasons are no longer on schedule, or happen differently? The title (and first sections) implies there will be some exploration of how traditions have changed with changes in climate, and since the book is about an exhibition of material culture, we might expect a look at how material culture (tools, clothing, modes of transport, etc.) has changed with the climate. This kind of analysis is not present in the book. However, the reader can make some of these connections on his/her own by exploring the plates and annotations in the catalogue. One might look through the objects and wonder if perhaps dog teams may be of more use on today's unpredictable sea ice, or that the increase in wind strength and frequency reported by Inuit may not be good for hunting by kayak.

Thin Ice is a beautifully produced book that will appeal to a diverse readership. The blend of text, photos, maps, and in particular the annotated presentation of Dartmouth's Arctic collection, provides a fascinating look into Inuit knowledge, use, and understanding of their environment.

\author{
Shari Gearheard \\ National Snow and Ice Data Center \\ Cooperative Institute for Research in Environmental Sciences \\ University of Colorado at Boulder \\ Mailing address: P.O. Box 241 \\ Clyde River, Nunavut, X0A 0E0 Canada \\ shari.gearheard@nsidc.org
}

VEBÆK, Mâliâraq

2006 The Southernmost People of Greenland - Dialects and Memories. QavaatOqalunneri Eqqaamassaallu, publié sous la direction de Birgitte Sonne avec une contribution de Birte $\mathrm{H}$. Christensen sur la phonologie, Copenhague, Meddelelser om Grønland, Man and Society, 33, 235 pages (avec CD).

The Southernmost People in Greenland fait appel à la tradition orale. Fruit d'une collaboration entre l'écrivaine kalaaliq Mâliâraq Vebæk et l'anthropologue danoise Birgitte Sonne, l'ouvrage présente un important corpus d'histoires et d'entrevues recueillies par Vebæk au cours des années cinquante et soixante dans les villages de l'extrême sud du Groenland (entre la municipalité de Qaqortoq et Nunap Isua/Kap Farvel). Elle-même originaire de la région, l'auteure a enquêté dans son dialecte natal qu'elle partageait avec ses informateurs - le groenlandais du sud-ouest, un parler se rapprochant à plusieurs égards du kalaattisit, le dialecte du Groenland de l'est.

L'intérêt de cet ouvrage est donc double, linguistique et ethnographique, d'où son sous-titre: Dialects and Memories. Sur le plan ethnographique, les 48 textes recueillis auprès de 22 informatrices et informateurs traitent de toutes sortes de sujets: récits de chasse et de voyage; scènes de la vie quotidienne; particularismes linguistiques du sudouest groenlandais; portraits d'individus; expériences troublantes; mythes; etc. Dans leur ensemble, ces textes constituent un aperçu intéressant et très rarement traité 